\title{
Ethnomedical Value of Plants in Nagapattinam District of Tamil Nadu, India
}

\author{
B. Vinoth, R. Manivasagaperumal ${ }^{\star}$ \\ Department of Botany, Annamalai University, Annamalai Nagar - 608002, Tamil Nadu, India \\ *E-mail address: vbvinobio@gmail.com
}

\begin{abstract}
The present survey was undertaken to explore the traditional knowledge of plant species found in four villages (Athamangalam, Vadukkuveli, Thalainayar and Perumangalam) in Sirkali taluk of Nagapattinam district, Tamilnadu state, The ethnomedicinal information was collected through oral interviews to village elders and vaidyas (those who cure disease by traditional methods) of the rural areas of this district. The knowledge available to the rural population of the area is transmitted only through oral language from generation to generation over time and therefore it needs to be recorded in order to be preserved. Medicinal plants are listed by botanical name, family name, local name, plant parts used and mode of preparation and the names of the diseases cured. About 50 plant species belonging to 27 families were described as effective herbal drugs for various ailments. The documented ethnobotanical uses of plants mostly related to the treatment in curing stomach pain, breast pain, headache, bleeding, yellow fever, muscle pain and blood purifier.
\end{abstract}

Keyword: Ethnomedicine; traditional medicine; Athamangalam; Nagapattinam and Tamilnadu

\section{INTRODUCTION}

The term ethnobotany was first coined by an American botanist, John Harshburger (1896), to study the plants used by the primitive and aboriginal people. Since then it has been defined as the traditional knowledge on indigenous communities, about surrounding plant diversity and as the study of how the people of particular culture and region make use of indigenous plants. Ethnobotany has its roots in Botany. Botany in turn originates in part from an interest in finding plants to help fight illness. In fact, medicine and botany have close ties. Many of today's drugs have been derived from plant resources.

Ethnobotany deals with the people of a particular culture and regions makes the use of indigenous plant while the ethnobotanist explores how plants are used for food, shelter, medicine, clothing, hunting and religious ceremonies. It is the relationship between a given society and its environment and in particular the plant world (Aumeeruddy, 1996).

The traditional knowledge of medicinal plants in India is enormous since many centuries based on different practical measures. It has been reported that traditional healers used more than 3000 plant species. Medicinal plants are considered to be the basic health care of rural households from the ancient days. A large number of medicinal plants are uninvestigated. The medicinal products from plants also have great interest in the process of 
drug discovery. Their vast diversity of plants in nature permits the identifications of molecules for the development of new therapeutic agents as well as biochemical and molecular mechanism of action involved in most physiological and pathological process. The medicinal properties of a plant depend upon the presence of certain chemical constituents. These chemical constituents seem to be responsible for curing disease. This chemical constituent have to be isolated, purified and identified as definite chemical compounds (Kumar and Chaturvedi, 2010).

The urbanization and industrialization lead to reduction in nature heritage, including the ethnic medicines of the Indian sub-continent. Only few of the ethnic groups in our country still retain their knowledge on the uses of medicinal plants, which are growing naturally in forests. From the literature survey, it is understood that the information available regarding the study of traditional medicines in Nagapattinam district of Tamilnadu is meager.

The rural communities, ethnic groups and folklore throughout the world are utilizing plant parts like root, stem, leaf, bark, flowers and fruits in various ways for the treatment of various ailments. An attempt has been made to record ethnomedicinally important plants and their useful parts. These plants have been successfully used in the different systems of medicines like Siddha, Ayurveda, Unani, Homeopathic and other. One of the major problems with this herbal formulation is that the active ingredients are not well defined. It is important to know the active component and their molecular interaction, which will help to analyze therapeutic efficacy of the product and also to standardize the product (Jayaprasad et al., 2011).

\section{STUDY AREA}

The district of Nagapattinam lies on the shores of the Bay of Bengal between Northern Latitude $10^{\circ} 46^{\prime}$ degrees and $79^{\circ} 49^{\prime}$ degrees Eastern Longitude an area of $2716 \mathrm{~km}^{2}$, which has a lot of herbs, shrubs and trees of important medicinal values.

\section{MATHODOLOGY}

The present study was carried out during 2012 to 2013 to collect data on traditional uses of medicinal plants used in the preparation of crude herbal drugs by the rural area people living in Sirkali taluk of Nagapattinam district. During this surveys personal interview were conducted with the village dwellers, the herbal medicine practioners and other traditional healers. Each of the plant material was assigned field book number and documented as to family, scientific name, vernacular name (Tamil), part used and medicinal uses, Plant parts that were identified as having use in ethnobotany were collected and Recorded.

\section{RESULTS AND DISCUSSION}

In the present investigation, we recorded around 50 species belonging 27 families used as herbal medicine for the treatment of various disease like Asthma, rheumatism, diarrhea, filariasis, diabetes, and yellow fever, and other. These have been successfully used in the 
different systems of medicines like Siddha, Ayurveda, Unani, Homeopathic and others. They utilize different parts of plants like roots, stem, leaf, bark, flower and fruits in various ways for the treatment of various ailments since ancient time. Some parts of the plants were taken internally in the form of powders, decoction and infusion. Some are made into paste and applied externally. The specific use of these herbal medicines depends upon the nature of diseases to be treated. The medicinal plants collected from the study area are listed below as the botanical name of the species. Family, vernacular name, plant organ used and mode of uses.

\begin{tabular}{|c|c|c|c|c|c|c|}
\hline S. No & $\begin{array}{l}\text { Botanical } \\
\text { name }\end{array}$ & Family & Local name & Habits & Part used & Treatment \\
\hline 1 & $\begin{array}{l}\text { Abutilon } \\
\text { indicum } \mathrm{L} \text {. }\end{array}$ & Malvaceae & Thuthi & Herb & Root & $\begin{array}{l}\text { Root extract is taken } \\
\text { orally twice a day for } \\
\text { two weeks to cure piles. }\end{array}$ \\
\hline 2 & $\begin{array}{l}\text { Acalipha indica } \\
\text { Linn. }\end{array}$ & Euphorbiaceae & Kuppaimeani & Herb & Leaves & $\begin{array}{l}\text { Leaf paste is applied } \\
\text { twice a day for } 1 \text { week to } \\
\text { cure bronchitis. }\end{array}$ \\
\hline 3 & $\begin{array}{l}\text { Achyranthes } \\
\text { aspera Linn. }\end{array}$ & Amaranthaceae & Nauruvi & Herb & Leaves & $\begin{array}{l}\text { Leaf paste with onion } \\
\text { paste is applied external } \\
\text { on the bitten site of dog } \\
\text { and to cure skin diseases. }\end{array}$ \\
\hline 4 & $\begin{array}{l}\text { Acorus calamus } \\
\text { (Linn). }\end{array}$ & Acoraceae & Vasambu & Herb & Rhizome & $\begin{array}{c}\text { As sedative, cancer, } \\
\text { pneumonia. }\end{array}$ \\
\hline 5 & $\begin{array}{c}\text { Adhatoda } \\
\text { vasica } \text { Nees. }\end{array}$ & Acanthaceae & Adhatoda & Shrub & $\begin{array}{l}\text { Leaves and } \\
\text { seed }\end{array}$ & $\begin{array}{c}\text { Leaves are used as } \\
\text { aromatic, antiarthritis, } \\
\text { antispasmodic, } \\
\text { bronchiodilator, diuretic } \\
\text { and sedative. } \\
\text { Poultice of seed } \\
\text { application is best to cure } \\
\text { inflammation, new } \\
\text { wounds and rheumatic } \\
\text { pains. }\end{array}$ \\
\hline 6 & $\begin{array}{l}\text { Aegle marmelos } \\
\text { Corv. }\end{array}$ & Rutaceae & Vilvam & Tree & $\begin{array}{l}\text { Roots, } \\
\text { leaves, } \\
\text { unripe } \\
\text { fruits and } \\
\text { ripe fruits }\end{array}$ & $\begin{array}{l}\text { Various parts of plant are } \\
\text { used to relieve thirst, } \\
\text { stomach pain, night } \\
\text { fever, breast pain. Fruit } \\
\text { decoction used for } \\
\text { treatment of intestinal } \\
\text { diseases. } \\
\end{array}$ \\
\hline 7 & $\begin{array}{l}\text { Aerva lanata } \\
\text { (L.) Juss. }\end{array}$ & Amaranthaceae & Sirukanpeelai & Herb & $\begin{array}{l}\text { Roots and } \\
\text { flowers }\end{array}$ & $\begin{array}{l}\text { Decoction of root and } \\
\text { flower are used to treat } \\
\text { kidney stone. }\end{array}$ \\
\hline 8 & $\begin{array}{l}\text { Alternanthera } \\
\text { sessilis DC. }\end{array}$ & Amaranthaceae & Ponnaanganni & Herb & Leaves & $\begin{array}{c}\text { Leaf is cooked and eaten } \\
\text { with normal diet for } 20- \\
30 \text { days to cure night } \\
\text { blindness. }\end{array}$ \\
\hline 9 & $\begin{array}{l}\text { Andrographis } \\
\text { paniculate } \\
\text { (Burm.F.) } \\
\end{array}$ & Acanthaceae & Nilavembu & Herb & Leaves & $\begin{array}{c}\text { The leaves are used as } \\
\text { chiken guinea, Swine flu } \\
\text { and Typhoid. }\end{array}$ \\
\hline 10 & $\begin{array}{c}\text { Annona } \\
\text { squamosa } \mathrm{L} \text {. }\end{array}$ & Annonaceae & Seetha & Tree & $\begin{array}{l}\text { Leaves, } \\
\text { bark }\end{array}$ & $\begin{array}{l}\text { Whole plant is used to } \\
\text { inhibit HIV replication. }\end{array}$ \\
\hline
\end{tabular}




\begin{tabular}{|c|c|c|c|c|c|c|}
\hline 11 & $\begin{array}{c}\text { Azadiracta } \\
\text { indica A. JUSS. }\end{array}$ & Meliaceae & Vembu & Tree & Flowers & $\begin{array}{l}\text { Flowers boiled in gingili } \\
\text { oil are applied on head } \\
\text { against dandruff once } \\
\text { days in the morning after } \\
\text { taking bathing. }\end{array}$ \\
\hline 12 & $\begin{array}{c}\text { Calotropis } \\
\text { gigantean } \mathrm{R} . \\
\mathrm{Cr} .\end{array}$ & Asclepiadaceae & Erik & Shrub & $\begin{array}{l}\text { Roots and } \\
\text { flowers }\end{array}$ & $\begin{array}{l}\text { Juice from the plant is } \\
\text { used to cure piles. } \\
\text { Root bark is made into a } \\
\text { paste and applied to treat } \\
\text { elephantiasis. } \\
\text { Flower decoctions are } \\
\text { good digestive and also } \\
\text { cure stomach ache. }\end{array}$ \\
\hline 13 & $\begin{array}{l}\text { Cardiospermum } \\
\text { halicacabum L. }\end{array}$ & Sapindaceae & Modukkathan & Climber & $\begin{array}{l}\text { Leaves and } \\
\text { whole } \\
\text { plant }\end{array}$ & $\begin{array}{c}\text { Leaf juices are taken } \\
\text { internally to treat } \\
\text { diabetes. They inhaling } \\
\text { leaf juice relieves head } \\
\text { ache. }\end{array}$ \\
\hline 14 & $\begin{array}{l}\text { Cassia } \\
\text { auriculate Linn. }\end{array}$ & Caesalpiniaceae & Aavaram & Shrub & Roots & $\begin{array}{l}30 \mathrm{~mL} \text { of the boiled } \\
\text { water extract of the roots } \\
\text { is taken twice a day for a } \\
\text { period of one month to } \\
\text { treat diabetes. }\end{array}$ \\
\hline 15 & $\begin{array}{l}\text { Cathranthus } \\
\text { roseas } \mathrm{L} .\end{array}$ & Apocynaceae & Nithyakalyani & Shrub & $\begin{array}{l}\text { Leaves and } \\
\text { Roots }\end{array}$ & $\begin{array}{l}\text { Leaf and root juices are } \\
\text { used daily two times to } \\
\text { cure diabetes. }\end{array}$ \\
\hline 16 & $\begin{array}{c}\text { Centella } \\
\text { asiatica (L.) } \\
\text { Urban. }\end{array}$ & Umbelliferae & Vallarai & Herb & Leaves & $\begin{array}{l}\text { Extract from the leaves } \\
\text { and whole plant are } \\
\text { taken internally for } \\
\text { improving memory } \\
\text { capacity and also used } \\
\text { externally to cure head } \\
\text { ache. } \\
\end{array}$ \\
\hline 17 & $\begin{array}{c}\text { Clitoria } \\
\text { ternatea } \mathrm{L} .\end{array}$ & Fabaceae & Sangupoo & Climber & Leaves & $\begin{array}{l}\text { Fresh leaf paste with the } \\
\text { paste of pepper (Piper } \\
\text { nigrum) is applied on } \\
\text { swelling of legs. }\end{array}$ \\
\hline 18 & $\begin{array}{c}\text { Cleome viscose } \\
\text { L. }\end{array}$ & Capparidaceae & Naaikkadukhu & Herb & Leaves & $\begin{array}{l}\text { Leaves paste is applied } \\
\text { for inflammations. }\end{array}$ \\
\hline 19 & $\begin{array}{c}\text { Coccinia indica } \\
\text { L. }\end{array}$ & Cucurbitaceae & Kovai & Climber & Leaves & $\begin{array}{l}\text { Leaves juice is taken } \\
\text { orally twice a day for } 2 \\
\text { days to cure fever. }\end{array}$ \\
\hline 20 & $\begin{array}{c}\text { Curcuma } \\
\text { aromatic Salisb. }\end{array}$ & Zingiberaceae & Kasthoorimanjal & Herb & Rhizome & $\begin{array}{l}\text { Dried rhizome is used } \\
\text { against various skin } \\
\text { diseases. }\end{array}$ \\
\hline 21 & $\begin{array}{c}\text { Cynodon } \\
\text { dactylon (Linn) } \\
\text { Pers. }\end{array}$ & Poaceae & Arugampullu & $\begin{array}{l}\text { Perennial } \\
\text { grass }\end{array}$ & Leaves & $\begin{array}{l}\text { Pounded leaves boiled } \\
\text { coconut oil is applied } \\
\text { once a day till the cure } \\
\text { various type of skin } \\
\text { diseases. }\end{array}$ \\
\hline 22 & $\begin{array}{l}\text { Cyperus } \\
\text { rotundus Linn. }\end{array}$ & Cyperaceae & Sarakontrai & Shrub & Root & $\begin{array}{l}\text { Decoction from the root } \\
\text { is useful to treat } \\
\text { intestinal problems, } \\
\text { stomach pain. } \\
\text { Root pastes are applied } \\
\text { to cure wounds sores etc. }\end{array}$ \\
\hline
\end{tabular}




\begin{tabular}{|c|c|c|c|c|c|c|}
\hline 23 & $\begin{array}{l}\text { Datura metal } \\
\text { Linn. }\end{array}$ & Solanaceae & Ummattai & Shrub & Leaves & $\begin{array}{c}\text { Dried leaf powder is } \\
\text { smoked as cigarette } \\
\text { twice a day for } 2-3 \\
\text { weeks to get relief from } \\
\text { asthma. } \\
\end{array}$ \\
\hline 24 & $\begin{array}{c}\text { Eclipta alba } \\
\text { Hossak. }\end{array}$ & Asteraceae & Karisalaganni & Herb & Leaves & $\begin{array}{l}\text { Leaf juice boiled with } \\
\text { coconut oil is used for } \\
\text { luxuriant black hair. } \\
\text { Extract from the leaves } \\
\text { cure skin diseases by } \\
\text { external application. }\end{array}$ \\
\hline 25 & $\begin{array}{l}\text { Emblica } \\
\text { officinalis } \\
\text { Gaertn. }\end{array}$ & Euphorbiaceae & Nellikka & Tree & $\begin{array}{l}\text { Root, bark, } \\
\text { leaves and } \\
\text { fruits }\end{array}$ & $\begin{array}{l}\text { Root and bark is } \\
\text { astringent, decoctions } \\
\text { from leaves are useful } \\
\text { for ulcers in mouth. } \\
\text { Fruits are used for } \\
\text { laxative and purgative } \\
\text { and also for abundant } \\
\text { growth of hair. }\end{array}$ \\
\hline 26 & $\begin{array}{c}\text { Euphorbia hirta } \\
\text { L. }\end{array}$ & Euphorbiaceae & $\begin{array}{l}\text { Amman } \\
\text { Pacharisi }\end{array}$ & Herb & Latex & $\begin{array}{c}\text { Juice from the plant is } \\
\text { given to treat dysentery } \\
\text { and colic, latex is applied } \\
\text { to cure warts. }\end{array}$ \\
\hline 27 & $\begin{array}{l}\text { Ficus } \\
\text { benghalensis } \\
\text { Linn. }\end{array}$ & Moraceae & Alamaram & Tree & $\begin{array}{l}\text { Stem, bark } \\
\text { and root }\end{array}$ & $\begin{array}{l}\text { The decoction obtained } \\
\text { is taken once a day for a } \\
\text { period of six weeks to } \\
\text { treat diabetes. }\end{array}$ \\
\hline 28 & $\begin{array}{c}\text { Gymnema } \\
\text { sylvestre (Retz.) } \\
\text { Schult. }\end{array}$ & Asclepiadaceae & Sirukurunjha & Herb & $\begin{array}{l}\text { Leaves and } \\
\text { roots }\end{array}$ & $\begin{array}{l}\text { In diabetes, digestive, } \\
\text { liver tonic and cardio } \\
\text { tonic. }\end{array}$ \\
\hline 29 & $\begin{array}{l}\text { Hemidesmus } \\
\text { indicus } \mathrm{R} . \mathrm{Br} \text {. }\end{array}$ & Asclepiadaceae & Nannari & Herb & Root & $\begin{array}{l}\text { Roots are made into a } \\
\text { paste and applied } \\
\text { externally to cure various } \\
\text { skin diseases. } \\
\text { Decoction from the root } \\
\text { as a good blood purifier } \\
\text { and also cure stomach } \\
\text { ache. }\end{array}$ \\
\hline 30 & $\begin{array}{l}\text { Hibiscus rosa } \\
\text { sinensis Linn. }\end{array}$ & Malvaceae & Sembaruthi & Shrub & $\begin{array}{l}\text { Flower and } \\
\text { Leaves }\end{array}$ & $\begin{array}{l}\text { Decoction of petals given } \\
\text { for bronchial catarrh and } \\
\text { also to strengthen the } \\
\text { heart. } \\
\text { Leaf juice is given for } \\
\text { blackening the hair. }\end{array}$ \\
\hline 31 & $\begin{array}{c}\text { Hyptis } \\
\text { suaveolens (L.) } \\
\text { Poit }\end{array}$ & Lamiaceae & Mint weed & Shrub & $\begin{array}{l}\text { Whole } \\
\text { plant }\end{array}$ & $\begin{array}{l}\text { Wound healing, cough } \\
\text { and chest pains, } \\
\text { Ringworm and } \\
\text { cosmetics. }\end{array}$ \\
\hline 32 & $\begin{array}{l}\text { Ipomoea } \\
\text { aquatic } \\
\text { Forsskal. }\end{array}$ & Convolvulaceae & Veelaikkeerai & $\begin{array}{c}\text { Terrestrial } \\
\text { Climber }\end{array}$ & Flower & $\begin{array}{l}\text { Flower juice is applied } \\
\text { once daily in early } \\
\text { morning around the eye } \\
\text { to cure black ring around } \\
\text { the eye. }\end{array}$ \\
\hline 33 & $\begin{array}{c}\text { Landana } \\
\text { camera Linn. }\end{array}$ & Verbanaceae & Unichedi & Shrub & Leaves & $\begin{array}{l}\text { Leaf paste is applied } \\
\text { topically to treat wounds } \\
\text { healings. }\end{array}$ \\
\hline
\end{tabular}




\begin{tabular}{|c|c|c|c|c|c|c|}
\hline 34 & $\begin{array}{l}\text { Leucas aspera } \\
\text { Spreng }\end{array}$ & Lamiaceae & Thumbai & Herb & $\begin{array}{l}\text { Leaves, } \\
\text { flowers } \\
\text { and roots }\end{array}$ & $\begin{array}{l}\text { Juice from the leaves is } \\
\text { applied in the affected } \\
\text { part to cure psoriasis; } \\
\text { flower dot decoction is } \\
\text { used to treat cold. } \\
\text { The whole plant } \\
\text { decoction is used to treat } \\
\text { worm's induced effects. }\end{array}$ \\
\hline 35 & $\begin{array}{c}\text { Madhuca } \\
\text { longifolia } \\
\text { (Koenig) }\end{array}$ & Sapotaceae & Eluppai & Tree & Seeds & $\begin{array}{l}\text { Pounded seeds mixed } \\
\text { with leaf extract of } \\
\text { Ocimum tenuiflorum are } \\
\text { applied on the affected } \\
\text { parts twice a day to cure } \\
\text { skin diseases. }\end{array}$ \\
\hline 36 & $\begin{array}{c}\text { Mimosa pudica } \\
\text { L. }\end{array}$ & Mimosaceae & Thotta sinungi & Herb & Roots & $\begin{array}{l}\text { Decoction of root is } \\
\text { taken orally once a day } \\
\text { for one week to get relief } \\
\text { from urinary complaints. }\end{array}$ \\
\hline 37 & $\begin{array}{c}\text { Momordica } \\
\text { charantia Linn. }\end{array}$ & Cucurbitaceae & Pagarkai & Climber & $\begin{array}{l}\text { Fruits, } \\
\text { seeds and } \\
\text { leaves }\end{array}$ & $\begin{array}{l}30 \mathrm{ml} \text { of the juice } \\
\text { prepared from few fresh } \\
\text { fruits and few fresh } \\
\text { leaves with pieces of the } \\
\text { stem bark of Syzygium } \\
\text { cuminii is taken once a } \\
\text { day to treat diabetes. }\end{array}$ \\
\hline 38 & $\begin{array}{l}\text { Murraya } \\
\text { koenigii L. }\end{array}$ & Rutaceae & Karuveppilai & Shrub & Leaves & $\begin{array}{c}\text { Juice taken tender leaves } \\
\text { is taken orally to arrest } \\
\text { vomiting. }\end{array}$ \\
\hline 39 & $\begin{array}{c}\text { Ocimum } \\
\text { basilicum L. }\end{array}$ & Lamiaceae & $\begin{array}{l}\text { Thirunitu } \\
\text { pacchilai }\end{array}$ & Herb & Leaves & $\begin{array}{c}5-10 \text { leaves are eaten as } \\
\text { raw twice day for cough } \\
\text { and cold. }\end{array}$ \\
\hline 40 & $\begin{array}{l}\text { Ocimum canum } \\
\text { Sims. }\end{array}$ & Lamiaceae & Nai thulasi & Herb & Leaves & $\begin{array}{l}\text { Malaria, fever, digestive } \\
\text { and cardio tonic. }\end{array}$ \\
\hline 41 & $\begin{array}{c}\text { Ocimum } \\
\text { sanctum } \mathrm{L} .\end{array}$ & Lamiaceae & Thulasi & Herb & Leaves & $\begin{array}{c}\text { Leaf juice is taken orally } \\
\text { twice a day for } 2 \text { days to } \\
\text { cure cough, cold and } \\
\text { fever. }\end{array}$ \\
\hline 42 & $\begin{array}{c}\text { Pedalium murex } \\
\text { L. }\end{array}$ & Pedaliaceae & Yaanai nerungil & Herb & Fruits & $\begin{array}{l}\text { Fruit decoction is given } \\
\text { to drink with } 50-100 \mathrm{ml} \\
\text { of hot water twice a day } \\
\text { for } 2-3 \text { days to cure } \\
\text { diarrhea. }\end{array}$ \\
\hline 43 & $\begin{array}{l}\text { Phyllanthus } \\
\text { amarus Schum } \\
\text { and Thonn. }\end{array}$ & Euphorbiaceae & Kizhanelli & Herb & $\begin{array}{l}\text { Roots, } \\
\text { stems, } \\
\text { leaves and } \\
\text { flowers }\end{array}$ & $\begin{array}{l}\text { Whole plant decoction } \\
\text { use to treat diabetes, and } \\
\text { also used to cure cough } \\
\text { and chest pain. The plant } \\
\text { extract are used } \\
\text { externally to treat } \\
\text { wounds. }\end{array}$ \\
\hline 44 & $\begin{array}{c}\text { Ricinus } \\
\text { communis Linn. }\end{array}$ & Euphorbiaceae & Amanakku & Shrub & Leaves & $\begin{array}{l}\text { One teaspoon of the } \\
\text { blend made by grinding } \\
\text { some shade dried leaves } \\
\text { and few shade dried } \\
\text { leaves of Phyllanthus } \\
\text { amarus (Kizhanelli) is } \\
\text { taken with ghee thrice a } \\
\text { day for one week to treat }\end{array}$ \\
\hline
\end{tabular}




\begin{tabular}{|c|c|c|c|c|c|c|}
\hline & & & & & & jaundice. \\
\hline 45 & $\begin{array}{c}\text { Solanum nigrum } \\
\text { Linn. }\end{array}$ & Solanaceae & Manathakkali & Shrub & Leaves & $\begin{array}{l}\text { Leaf juice applied } \\
\text { externally to cure itching }\end{array}$ \\
\hline 46 & $\begin{array}{c}\text { 'Tephrosia } \\
\text { purpurea (L) } \\
\text { Pers. }\end{array}$ & Fabaceae & Kaavaalai & Herb & $\begin{array}{l}\text { Roots, } \\
\text { leaves, } \\
\text { seeds and } \\
\text { whole } \\
\text { plant }\end{array}$ & $\begin{array}{l}\text { Decoction from the plant } \\
\text { as a good blood purifier. } \\
\text { Dried herb made as a } \\
\text { paste and applied for the } \\
\text { treatment of boils and } \\
\text { pimples. Juice of leaves } \\
\text { is beneficial in diabetes. }\end{array}$ \\
\hline 47 & $\begin{array}{c}\text { Vetiveria } \\
\text { zizanoides Nast }\end{array}$ & Poaceae & Vetiver & Herb & Root & $\begin{array}{l}\text { As febrifuge, diaphoretic } \\
\text { and stomach ache. }\end{array}$ \\
\hline 48 & $\begin{array}{l}\text { Vitex negundo } \\
\text { L. }\end{array}$ & Verbenaceae & Karinotchi & Shrub & $\begin{array}{l}\text { Root, } \\
\text { stems, } \\
\text { leaves, } \\
\text { seeds and } \\
\text { whole } \\
\text { plant }\end{array}$ & $\begin{array}{l}\text { The whole plant } \\
\text { decoction is used to treat } \\
\text { cough, fever and asthma. } \\
\text { Roots tincture is used in } \\
\text { rheumatism. Leaves are } \\
\text { effective in gonorrheal } \\
\text { epididymitis and as } \\
\text { vermifuge. }\end{array}$ \\
\hline 49 & $\begin{array}{l}\text { Wrightia } \\
\text { tintoria } \mathrm{R} . \mathrm{Br} .\end{array}$ & Apocynaceae & Veppalai & Tree & Leaves & $\begin{array}{l}\text { Pounded leaves mixed } \\
\text { with coconut oil are } \\
\text { applied twice a day. To } \\
\text { cure psoriasis. }\end{array}$ \\
\hline 50 & $\begin{array}{c}\text { Zingiber } \\
\text { officinale Rosc. }\end{array}$ & Zingiberaceae & Inji & Herb & Rhizomes & $\begin{array}{l}\text { Decoction of ginger can } \\
\text { treat respiratory tract } \\
\text { problems, cold and } \\
\text { cough. Syrup of ginger } \\
\text { is used to treat head } \\
\text { ache, impotency and } \\
\text { menstrual disorders. }\end{array}$ \\
\hline
\end{tabular}

\section{CONCLUSION}

Herbal medicine is the best and cost effective medicine in curing of many diseases. It cures many diseases which are not cured by other system of medicines like, western medicines. The elders of this area are using number of medicines of plant origin. The information may be useful in the field of ethnobotany. Some of these plants were traditionally used and very few active constituently chemical compounds have been isolates and identified. This article may give rise a new pathway for researcher who works in the field of ethno medicine to isolate the active compound for particular diseases.

\section{References}

[1] Aumeeruddy Y. (1966). Ethnobotany, linkages with conservation and development. In: Proceeding of first trading workshop on Ethnobotany and its applications to conservation NARC, Islamabad, pp. 152-157.

[2] Jayaprasad B., D. Thamayandhi, P. S. Sharavanan, Int. J. Res. Pharm. Biosci. 2(1) (2011) 1-8. 
[3] John Harsh Burger J. W., Botanical Gazette 21 (1896) 146-154.

[4] Kumar G. P., A. Chadurvedi, Ethnobotanical leaflets 14 (2010) 674-680.

[5] S. Dhanam, International Letters of Natural Sciences 11(2) (2014) 197-208.

( Received 09 June 2014; accepted 20 June 2014 ) 